\title{
SAINT AMBROSE OF MILAN AND THE ESTABLISHMENT OF CHRISTIANITY WITHIN THE CONVENTIONS OF THE NEW LANGUAGE FOR THE CHRISTIANS
}

\footnotetext{
1. The historic, political and theological circumstances of the first ecumenical councils within their linguistic complexity. By successful opening with the speech of the Emperor Constantine in Latin the Nicaea Council was continuing the old Western and Eastern tradition of using the Latin language in cases of establishing the imperial laws ${ }^{1}$. But the Bible was not yet translated to Latin, and in the Council's Canons there were only two passages from the Bible, one from the Book of Psalms and one from the New Testament (Ps 14, 5; 1 Tim $3,6-7)^{2}$. By the $18^{\text {th }}$ canon the liturgical order in the moment of receiving of the Holy Communion (Holy Eucharist) determined the first form of future ecclesiastical hierarchy ${ }^{3}$. The finished Nicene Creed as a derivation from the baptismal habit of Caesarea, proposed to Council by Eusebius, or, regarded as its combination with the creed of Jerusalem or Palestine, has been preserved in the writings of Athanasius ${ }^{4}$, historian Socrates 5 and Theodoret of Cyrus ${ }^{6}$, but survived only in the acts of the Council of Chalcedon of $451^{7}$, where in the session of 8 and 10 October 451 after the reading out of Nicene Creed the bishops acclaim: "This is the faith of the orthodox. This is how we all believe". Among the various editions of the canons in the eastern and western

* Neža Zajc, Ph.D. - Researcher assistant at the Institute of Cultural History, Scientific Research Center of Slovenian Academy of Sciences and Arts, Ljubljana, Slovenia; e-mail: nzajc@zrc-sazu.si.

${ }^{1}$ Cf. L.D. Davis, The First Seven Ecumenical Councils (325-787), Their History and Theology, Delaware 1987, 59.

${ }^{2}$ Cf. Concilium Nicaenum I (325) can. 2 (De neophytis); can. 17 (De clercis qui usuras accipiunt).

${ }^{3}$ Cf. ibidem can. 18 (De privilegiis presbyterorum).

${ }^{4} \mathrm{Cf}$. Athanasius Alexandrinus, Epistula ad Iovianum imperatorem 3; idem, De decretis $\mathrm{Ni}$ caenae Synodi 33, 3. See G.C. Stead, Homoousios dans la pensee de saint Athanase, in: Politique et Theologie chez Athanase d'Alexandrie, ed. C. Kannengiesser, Paris 1974, 231-253; Atanasio. Il Credo di Nicea, ed. E. Cattaneo, Roma 2001; F.L. Cross, The Study of Athanasius, Oxford 1945; G.L. Prestige, Fathers and Heretics, London 1940.

${ }^{5} \mathrm{Cf}$. Socrates, HE I 8.

${ }^{6} \mathrm{Cf}$. Theodoretus Cyrensis, HE IV 3.

${ }^{7}$ Cf. Davis, The First Seven Ecumenical Councils, p. 59.

${ }^{8}$ ACO II 1, 2, Berlin 1914, 80.
} 
collections it is worth to mention the Greek text from John Scholasticus and the Latin of Dionysius Exiguus (additionally to the old Latin translations in the Prisca, in Dionysius Exiguus and Pseudo-Isidore). It was Apollinaris of Laodicea (bishop, 361-390) who attempted to rewrite the Holy Scripture in classical forms, and in Antioch Jerome attended his lectures. But there were soon noticeable important theological concepts that differed from the Orthodox Christology in the Apollinaris's thought. In 375 he consecrated a disciple, Vitalis, as the fourth bishop of Antioch, and at the same time Apollinaris caused the reaction of Basil of Caesarea, who denounced him to Damasus of Rome. In 377 Roman Council condemned Apollinaris, as well as in 379 in Antioch by protest of Gregory of Nyssa and Gregory of Nazianzus, and on the Constantinopolitan Council in 381.

At the I Constantinopolitan Council (mid May - $9^{\text {th }}$ July 381), which was only after the Council of Chalcedon in 451 regarded as Ecumenical ${ }^{9}$, summoned by Theodosius I in an agreement with the Emperor Gratian, and whose valuable content could be found in the testimonies of eyewitnesses (in Gregory of Nazianzus' Carmen historicum ${ }^{10}$, and in his final speech in front of the council $^{11}$; in Gregory of Nyssa's memorial speech on the occasion of Meletius' death $^{12}$ ) the Church fathers were still referring only quite limited quantity of passages from the Holy Scripture. In the documents of the Council there were four references from the Old Testament - the first three related to three verses from the psalms (Ps 50; 54; 65) and one from the Prophet Isaiah $(53,5)$, and only a few from the New Testament: one from the Acts of Apostles $(7,58)$ and others, especially from the Epistles of Saint Apostle Paul (Rom 14, 10; 1Cor 1, $12 ; 1,13 ; 4,8 ; 12,25.27 ;$ Gal 6, 17; Col 1, 18, 24; Heb 4, 16). The latter could be understood by an awareness of the complexity of biblical message transmission to the believers and with an important reference to a higher impact of theoretically ideal language, shaped in the speech by the Apostle Paul about the specific concatenation of the glossolalia and the prophecy (the identity of the languages, the first dedicated to God and the other assigned for the people). Despite that this was also a period when the first five "Christian Histories" had appeared $^{13}$, the council resolution was still distant from the explicit ecumenical

\footnotetext{
${ }^{9}$ Cf. Davis, The First Seven Ecumenical Councils, p. 121.

${ }^{10} \mathrm{Cf}$. Gregorius Nazianzenus, Carmen historicum 11, 1509-1549.

${ }^{11}$ Cf. idem, Oratio 42.

${ }^{12} \mathrm{Cf}$. Gregorius Nyssenus, Oratio funebris in Meletium 1, 3.

${ }^{13}$ At that time the first five attempts in Greek and the old Latin were being written (translations in Prisca) to build the reliable "History of Christian Church". From Greek to Latin Historia Ecclesiastica was translated, written in Greek koine (in the year 326) by Eusebius from Ceasarea. Socrates (in the year 439), Sozomenus (during the years 440-443, dedicated to Theodosius II) and Theodoret of Cyrus in Historia ecclesiastica (events up to the year 429) had attributed three further canons to the Council of the year 381. After the death of Theodosius (in the year 395), Rufinus from Aquileia wrote Historia Ecclesiastica. Soon Augustine began to write his monumental work The City of God
} (in the year 412). 
character ${ }^{14}$, yet it was therefore the central polemic discussion dealing with the problem of numerous heretical controversies (Eunomians or Anhomoians, Arians or Eudoxians, Semi-Arians or Pneumatomachi, Sabbelians, Marcellians, Photinians, Apollinarists) $)^{15}$. This politico-theological position was also influencing the view shaping by promoting the bishop of Rome at the I Constantinopolitan Council (in 381), wherein Constantinople was declared the "new Rome" ". The Greek collection of canons however, divided the Constantinopolitan decree to four sections, consequently called "kanones", differing from the reports made by the first three "Christians Histories" of Socrates, Sozomenus and especially of Theodoret of Cyrus, as well as from the old Latin translations in the Prisca, in Dionysius Exiguus and Pseudo-Isidore, that did not preserve the notifications about the three further canons, added to the Constantinople Council of 381 in Greek texts. It has to be said that the final version of The symbolum Constantinopolitanum or Nicaeno-Constantinopolitanum which unified all imagined Christian countries like no other ${ }^{17}$, is nowadays, presumably because of Filioque, which prevailed in the West from the seventh to the ninth century, understood as the main dogmatic reason for the schism between the Roman Catholicism and Byzantine Orthodoxy. In the assemblage of texts that the Greek acts of the Council embedded at Chalcedon 451 there was also the decree or synodicon (the regulations) of the first Constantinopolitan Council - The symbolum Constantinopolitanum. The latter, which united

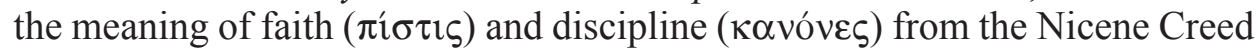
was at that time obviously still under dominating influence of Constantine who began restructuring the Church. As a result, by second canon the Constantinopolitan Council established autonomous metropolitan dioceses or ecclesiastic eparchies to prevent further transgressions of authority; the Patriarch of Constantinople was promoted directly after the bishop of Rome since this city was, according to the third canon, "the new Rome" (iunior Roma) ${ }^{18}$. Next year the Church authorities gathered at the same place, yet the synodal letter of the Council of Constantinople of 382, in the Greek original preserved in

${ }^{14}$ Cf. Concilium Constantinopolitanum I (381), in: Conciliorum Oecumenicorum Generaliumque Decreta I, editio critica, vol. 1: The Oecumenical Councils, From Nicaea I to Nicaea II (325-787), ed. G. Alberigo - A.M. Ritter - L. Abramowski et alii (= COGD), Bologna 2006, 50-51; ibidem can. 8 (Quomodo recipiendi sint qui ad rectam fidem accedunt), COGD 1, 94.

${ }^{15}$ Cf. ibidem, COGD 1, 41.

${ }^{16}$ Cf. ibidem can. 3 (Ut secundus post Romanum episcopum Constantinopolis episcopus sit), COGD 1, 66. Third Canon had a significant influence on the proceedings of the following Ecumenical Councils, especially on the Council of Constantinople I (381); the Council of Ephesus (431); the Council of Chalcedon (451); the Council of Constantinople II (553); the Council of Constantinople III (680-681); the Council of Trulle (691-692) and the Council of Nicae II (787).

${ }^{17}$ Cf. COGD 1, 49.

${ }^{18}$ Concilium Constantinopolitanum I (381) can. 3 (Ut secundus post Romanum episcopum Constantinopolis episcopus sit), COGD 1, 66. 
Thedoret's Historia ecclesiastica ${ }^{19}$, was addressed to a synod of Rome, signed by bishops Damasus, Acholius and Ambrose. The latter, a Christian catechumen and civil governor of the province Liguria-Emilia, a son of the praetorian prefect, who was in 373 elected bishop of Milan, directly influenced the Emperor Gratian's announcement of the series of laws in the West, and at the Council of Sirmium in 378 Ambrose deposed six Arians bishops ${ }^{20}$.

At the formal proposal, inspired by Theodosius, authored by Ambrose of Milan, the protest of the Western bishops against the decision of Constantinople was expressed in 381, particularly the decisions on the episcopate of Constantinople and the provisory decisions on the succession of Meletius in Antioch ${ }^{21}$. Their demand of the summa of "all Catholic priests" 22 and therefore, following the Nicene decree in the organization of the Church, according to which each eparchy is made by its bishop (exactly as in the East bishop's appointments), was measured by motions and terms of Ambrose of Mediolanum who expressed doubts about the orthodoxy of the leading circle (Meletians) of the Council of Constantinople in $381^{23}$. Consequently, Ambrose influenced the reaffirmation of relations between the Nicene of East and the West over the previous decade ${ }^{24}$. Again, the introduction of the above-mentioned epistle to Rome survived only in the Historia ecclesiastica of Theodoret of Cyrus $^{25}$, and in the Epistles of St. Ambrose ${ }^{26}$. But between the two mentioned Constantinople Councils (in the years 381 and 382) there was also one local Council at Aquileia that has to be mentioned, particularly concerning the role of the bishop of Milan, Ambrose. There were also Eastern bishops invited, yet nobody came; only the leader of anti-Niceans, Palladius of Ratiaria, the Bishop of Belgrade, Secundianus, and priest Attalus of Poetovio (Ptuj) ${ }^{27}$ arrived. The core of the council consisted of ten Italian bishops, two legates from Africa, two official delegations from Gaul, half-dozen Gallic bishops and four Illyricans ${ }^{28}$. The president of the Council was the Bishop Valerian of Aquileia and the two stenographers who recorded were clerics from Ambrose's church. The information about the Council survived in the $5^{\text {th }}$ century manuscript of Acta with preservation of Palladius' commentaries on Ambrose's questions after his introduction by citing the letter of Arius. Palladius, to whom Ambrose

\footnotetext{
${ }^{19} \mathrm{Cf}$. Theodoretus Cyrensis, HE V 8, 10.

${ }^{20}$ Cf. Davis, The First Seven Ecumenical Councils, p. 116.

${ }^{21}$ Cf. COGD 1, 44.

${ }^{22}$ Cf. Ambrosius, Epistula 6 [extra coll.], 5, SAEMO 21, ed. G. Banterle, Milano - Roma 1988, 202.

${ }^{23}$ Cf. idem, Epistula 9 [extra coll.], 6.

${ }^{24} \mathrm{Cf}$. Theodoretus Cyrensis, HE V 9, 8.

${ }^{25}$ Cf. ibidem V 9, 14-18.

${ }^{26}$ Cf. Ambrosius, Epistula 6 [extra coll.], 4-5; ibidem 13, 6.

${ }^{27}$ Cf. J. Moorhead, Ambrose. Church and Society in the Late Roman World, London - New York 1999, 119.

${ }^{28}$ Cf. N.B. McLynn, Ambrose of Milan. Church and Court in a Christian Capital, Berkely
} 1994, 126. 
posed a question about the Arius' term of the God Father as solus immortalis, and posed a request to say verum deum filium dei, answered with references from the Bible and by silence ${ }^{29}$, but instead of him Eusebius of Bologna, after Ambrose, repeated the canonical sentence. Ambrose invoked the chorus of anathematizing bishops and the Council concluded condemning the three anti-Nicene clergy (the document was submitted to Gratian, Valentinian and Theodosius) $)^{30}$. The synod of Aquileia has never considered recognizing Rome as the instance, which should always have the first and the last word in churchly matters, but the statement that the bishop of Rome was the first in the hierarchy of the West was accepted. Consequently the breakdown in the communication between Rome and Aquileia happened, because the Council of Aquileia in certain aspect enforced the legitimate interests of Antioch, where soon after that two pro-Nicene bishops were again promoted to supervisors: Melitus enjoyed the local support and Paulinus was backed by the Churches of Rome and Alexandria. Nevertheless the proposal by Ambrose to Melitus was a rather ambitious decree (while Melitus enjoyed overwhelming local support and "the council of Aquileia attempted to resolve this delicate situation by decreeing that, on the death of one of the rivals, the other was to assume control over the whole church in the city") ${ }^{31}$. Although the council of Aquileia the dispute within the church of Antioch had not successfully solve, it showed the position of Ambrose as the bishop of Milan, who was deeply considering all the above-mentioned problems concerning the proper "new" Christian language, the anti-Arian thought, the problem of History of the Christian Church, the liturgy and also the problems concerning the martyrs: the inscriptions, dedications and consecrations of Constantine monuments, especially concerning martyrologium, were shaping not only the main Roman Christian Churches as imperial frontispieces, but were giving the base for the Christian iconography ${ }^{32}$. The tedious problem of their non-touchable relics was the main non-evident nuclei of the Christian self-identification: the main reason making the possible transfer of relics a problematic issue was moving them in the direction from the West to the East; the transplantation of the relics to the Eastern centers of Christianity was officially established in 357 in Milan, where Constantius II announced the law, according to which the relics must not be touched; 30 years later in Constantinople an act specified that the relics must not be transferred ${ }^{33}$. However, the speech by Ambrose at the Aquileia Council, which was addressing his opponents in the equal status to himself, reflected

${ }^{29}$ Cf. ibidem, p. 131.

${ }^{30}$ Cf. Moorhead, Ambrose, p. 121.

${ }^{31}$ Cf. ibidem, p. 122.

${ }^{32}$ Cf. E. Livrea, L'imperatrice Eudocia e Roma, ByZ 91 (1998) 78-79.

${ }^{33}$ Cf. C. Mango, Constantine' Mausoleum and the Translation of Relics, in: idem, Studies on Constantinople, Ashgate 1993, 51. 
the biblical Greek, but certainly not Latin, theological discourse ${ }^{34}$. It is even more evident, that Ambrose's source for the Christian language was the Septuagint, within the context of his readings the original text in Greek, as well as the deuterocanonical books of the Bible (for example the "4 Maccabees") ${ }^{35}$.

Many of the above-mentioned difficulties of the first ecumenical Councils can be explained by a linguistic position, more precisely, by the non-established limits of the languages of the old and the new religion in the $4^{\text {th }}$ century. The fact that in the time when Constantine became the Emperor the Christians represented less than $20 \%$ of the Roman nation affirms such unbalanced position in the meaning of the theological and biblical terminology of the two languages, Greek and Latin, but at the end of the $4^{\text {th }}$ century the pagans already became the minority of the population and the Christians took over the main court and public positions, from the clerics to the laymen. However, the Latin grammar was being already formed, the Latin grammarian of Constantinople Priscian wrote his magisterial work Institutiones grammaticae (around the year 500), previously only Donatus's Ars grammatica from the $4^{\text {th }}$ century existed (in comparison with Greek: Alexandrian grammarian Apollonius Dyscolus' works on syntax Techne grammatike were written around year 200) ${ }^{36}$. The Latin, as the language of the Christians, was characterized by the tendency of an enforced literacy and extreme correctness ${ }^{37}$. Consequently, only the Bible within the poetical forms of the Old Testament and the allusions on the revelation of the New Testament ascribed the non-written rules of that style, which a Christian author, willing to imitate the biblical speech and language, could follow. The increasing number of common Christian words, not new but with the meaning of circumstances of the everyday (real, realistic) life of Christian communities, began to spread in colloquial (spoken) language. It could be recognized that such language was as much as possible close to the language of apostles and first Christian preachers. This is why the Christian religion at that time could be recognized primarily by the presence of words deriving from liturgical service. It was in the Church during the liturgy when two languages existed at the same time and where the literary and canonical conventions of Latin were refined.

2. St. Ambrose's impact on the liturgical language. Ambrose's interpretations of the Bible notably reflected how he was encouraged to meditate and to contribute in the primary Greek language of the Holy Scripture (the confirmation of the manner in which he was handling the Bible; it was a close,

${ }^{34}$ See more M. Poirier, “Christus pauper factus est” chez Saint Ambroise, RSLR 15 (1979) 250-257.

${ }^{35} \mathrm{Cf}$. Ambrosius, De Iacob et vita beata 3, 6-18.

${ }^{36}$ Cf. R.H. Robins, The Byzantine Grammarians, New York - Berlin 1993, 15 and 87.

${ }^{37}$ Cf. J. Clackson - G. Horrocks, The Blackwell History of the Latin Language, Chichester 2011, 284-286. 
silent, mostly night-time reading that allowed him to re-interpret the biblical text from the daily liturgy during which he was leading and supporting voices in vice versa; at the liturgy service he was meditating the passage that he read at night time). Ambrose directly interpreted the bilingual structure of the language that he introduced - that was the spoken one, as he was preaching to the Christian believers. Ambrose was obviously consciously enforced to build - not in the artificial manner - the homiletic language for the Christian liturgy which by important development in the form of Kontakion in the Orthodox Church remained until the end of $7^{\text {th }}$ century, when at the Council of Trullo such form was replaced by $\mathrm{Kanon}^{38}$, and the homiletic language was replaced by at that time already confirmed and defined biblical one. Moreover, Ambrose's treatises profoundly reflected continuous Nicene (foretelling the future pentarchial) atmosphere at the Constantinople Council in the year 381 where by the fifth canon there was defined the churchly recognition of all confessing the "single" Divine nature of the Father, the Son and the Holy Spirit (the strongly and strictly defined Trinitarian and Christological aspects, again preserved in Theodoret's Histori $a^{39}$ ). In that manner Ambrose was answering to the opponents who noted his unwillingness to cite the texts of Arius and the subsequent anti-Nicene thinkers (Aetius, Eunomius) in his De fide ${ }^{40}$. Ambrose simply responded that these authors "all speak the same thing" ${ }^{41}$. Nevertheless the latter was not quite equal to the truthful meaning, Ambrose's answer reflected his concept of bishop as priest deriving by apostolic succession authority from the earthly Christ ${ }^{42}$, which was consequently adopted by the imperial ideology of Constantine the Great and directly in his theoretical ground of near-future establishing the Eastern monopoly.

Nevertheless Ambrose was very much affiliated in the literal (direct) meaning of the biblical words, and their use in the everyday life, his vocabulary showed that he accepted also the word content, related to the Greek (his language could not yet be coherent). The most doubtless linguistic formula of the interpretation of the Holy Scripture, accompanied with the imperial context, as well as a satisfactory argument against Arians, was offered in his writings about virginity - De virginibus, De virginitate - and paradoxically, in the discourse on the death of Theodosius - De obitu Theodosii. In the latter, among the sacred patriarchs of Genesis, Ambrose also inserted a certain inclusion of Constantine the Great directly to the heavenly company (also mentioning his mother Helena and her finding of three crosses at Jerusalem), in association

\footnotetext{
${ }^{38}$ Cf. E. Wellesz, A History of Byzantine Music and Hymnography, Oxford 1998², 204.

${ }^{39} \mathrm{Cf}$. Theodoretus Cyrensis, HE V 9-11.

${ }^{40} \mathrm{Cf}$. Ambrosius, De fide III 14.

${ }^{41}$ Ambrosius, De fide I 6, SAEMO 15, ed. C Moreschini, Milano - Roma 1977, 378-380, transl. H. De Romestin: Ambrose, Select Works and Letters, ed. P. Schaff - H. Wace, The Nicene and PostNicene Fathers, vol. 10, Grand Rapids 1896, 207; cf. Moorhead, Ambrose, p. 114.

${ }^{42}$ Cf. Davis, The First Seven Ecumenical Councils, p. 74.
} 
with introducing the new meaning of the Christian faith, the Orthodox faith, into the Christian consciousness ${ }^{43}$. Ambrose was even more correct in the definition of the word "gentes" that had to be distinguished from "gentiles", the term that Ambrose used for Jews ${ }^{44}$. It was therefore not yet canonical that St. Ambrose that in his writings understood the Old Testament presumably as Christological and Christocentric, but used the language of the Gospels (mainly from the Gospel of Luke). Ambrose's unique piety reflected in his naming Jesus Christ as Jesus the Lord ${ }^{45}$, which Ambrose used for the cause of an intimacy of the second person singular to invite his listeners to follow him ${ }^{46}$. Such appeal to the Christ Himself, that expressed the personal necessity for the pronunciation of the name "the Son of God", was later heard at the Council of Ephesus, where the Church fathers asked (prayed for) the help from Christ Himself as a judge to the Council against the heretical thought of Nestorious ${ }^{47}$.

Nevertheless, Ambrose was aware of a non-satisfactory purpose both of the words and of the images from the Holy Scripture. From the exegetical point of view he was quite distant from the modern understanding of an exegesis, thus also distant from the known allegoric circle or even from the parabolic one. Beside the mentioned fulfillment of the Zacharias' prophecy by the first Christian emperor Constantine the Great, in the text De virginibus Ambrose stressed the mutual position of the female and the child, their solid ability of the straight fidelity, their faithfulness to the patrimonial tradition, and therefore also the adherence to the Roman ground ${ }^{48}$. Along his interpretation of Song of Songs in the similar manner, in the text De virginibus, he even more firmly stated the unique position of the sacred female personalities of the Bible ${ }^{49}$. By this example of an inter-biblical genealogy of the pure female beings, it is clearly shown how this unique superior concept, examined on the irreproachability of female figures from the Old Testament and reserved for the evangelic presence of the Mother of God, was a principle for St. Ambrose to denote not so much the already known certain allegoric interpretations, but rather the possibility of "the expression of the inexpressible", according to which each personality from the Holy Scripture needs the decoding of its mysterious perspective which in consequence resulted in the most intimate manner. Indeed, Ambrose read the Old Testament in the Christocentric perspective ${ }^{50}$. From a theological aspect the mentioned strictly biblical interpretation of an eternal (timeless) meaning of the heritage of the Mother of God at that time could be found in the

\footnotetext{
${ }^{43}$ Cf. Moorhead, Ambrose, p. 203.

${ }^{44}$ Cf. Ambrosius, Epistula 72, 16. See Moorhead, Ambrose, p. 125.

${ }^{45}$ Cf. Ambrosius, Expositio Evangelii secundum Lucam 10, 158-160.

${ }^{46}$ Cf. ibidem 10, 138.

${ }^{47}$ Cf. COGD 1, 75.

${ }^{48} \mathrm{Cf}$. Ambrosius, De virginibus I 2, 9.

${ }^{49} \mathrm{Cf}$. Moorhead, Ambrose, p. 52-54, and note 44 on page 67.

${ }^{50}$ Cf. ibidem, p. 81 and 87-88.
} 
works of Gregory of Nyssa, particularly in his meditation on Song of Songs ${ }^{51}$, where he found the place for Christ's bride ${ }^{52}$ as the Church of Christ - in an analogue apologetic, but non polemic, nearly arithmetical manner ${ }^{53}$, which St. Ambrose interpreted in the most direct manner: as he was seeing exactly each biblical personage denoting the Church was a woman, and even more precisely - Mary ${ }^{54}$, who represented the Church to St. Ambrose ${ }^{55}$. It deserves an attention that such timeless maxim with the significant inclusion of Constantine's involvement was found exclusion among the contemporaries and in the Patristic writings, but both mentioned topics concerning the Mother of God and presumably Constantine the Great were later adopted by the main byzantine hymnographer Roman Melodos ${ }^{56}$ in his Hymns as well in his Akathist, for example in his Akathist on the Annunciation ${ }^{57}$. With that kind of a mystical context of the presence of Christ's Mother in the Holy Scripture, Ambrose was able to respond to several crucial questions that were the cause of the main conflicts between the Christians and the Pagans (as the subject of virginity, resulted from the previous position in the Roman Empire of Vestinae $)^{58}$. All mentioned complexity could be reached at the Christian monuments, dated earlier, more exact, in the catacombs and basilica of Sant'Agnese, built on the request of the emperor Constantine the Great - because the prayer on the tomb of the martyr Agnes helped his daughter to recover from her disease ${ }^{59}$. The inscriptions engraved in the floor and in the ceiling of catacombs of Sant'Agnese clearly testify the date of the exact connection between the new consecration of the church to Christian martyr Agnes ${ }^{60}$ and the liberation of Rome by

${ }^{51}$ Cf. ibidem, p. 108-109.

${ }^{52}$ See forthcoming A. Louth, "From Beginning to Beginning": Endless Spiritual Progress in St. Gregory of Nyssa, in: The Proceedings of the XXI International Ecumenical Conference on Orthodox spirituality "The Ages of the Spiritual Life", ed. E. Bianchi, Bose 2013.

${ }^{53}$ See more: J. Riviere, "Trois cent dix-huit". Un cas de symbolisme arithmetique chez S. Ambroise, RTAM 6 (1934) 361-367.

${ }^{54}$ Cf. Moorhead, Ambrose, p. 108.

${ }^{55}$ Cf. ibidem, p. 99.

${ }^{56}$ Cf. ibidem, p. 204, note 32.

${ }^{57}$ Cf. L'inno Acatisto in onore della Madre di Dio, ed. C. del Grande, Firenze 1948, 76-81, $82-$ 83. See Roman's Canon to the Death of John the Baptist (Canon Funebris ad Iohannes Baptista), in: H.J. Tillyard, Byzantine Music and Hymnography, London 1923, 16. It was another byzantine hymnographer, called Roman II (959-963), who produce also such liturgical hymns, see: the Holy Mount Athos, Monastery Vatopedi, Manuscript № 574, coll. Zach. 1, p. 75-76 (V.N. Beneševič, Сведения о греческих рукописях канонического содержания в библиотеках монастырей Ватопеда и Лавры св. Афанасия на Афоне, Санкт Петербург 1904, 40-42).

${ }^{58} \mathrm{Cf}$. Ambrosius, De virginibus I 4, 15.

${ }^{59}$ Although the Liber Pontificalis attributes to Constantine the construction of the church nearby, Sant'Agnese fuori le Mura, the church was planned by the daughter of Constantine. Cf. T.D. Barnes, Constantine: Dynasty, Religion and Power in the Late Roman Empire, Chichester 2011, 88; R. Krautheimer, Corpus Basilicarum Christianorum Romae, vol. 1-2, Roma 1937, 14-39.

${ }^{60}$ The Church in the Catacombs with the very first inscription of the name of "Vestinae" was 
Constantine the Great in October $312^{61}$. In the third year of his episcopate (377) Ambrose, at the request of his sister Marcellina, and addressed to her, gathered up his teachings about the state of Virginity in three books. In the first among them, he treated the dignity of Virginity and commenced his addresses on the anniversary of the martyrdom of St. Agnes, especially contemplating the circumstances of the death of the martyr Agnes ${ }^{62}$, where he described her pious position among the witnesses of the Christian faith: the life, closed to the end of the martyr's body, was equal to the Christian fidelity. St. Ambrose wrote a significant hymn (ode) to virgin Agnes, in which the meaning of her name, the genitive of the Greek "Agne", is inscribed as "Nome virginis titulus est pudoris" 63 , and the phonetic similarity originated in the iconographic type of the Saint with a lamb in the arms. Of course, the Christian monuments of the archaeological complex of Sant'Agnese show no clear iconographic rule, but the fresco in the catacombs depicted the subject of mutual unit of the Mother and the Son and reflected the portraits of imperial family, later recognized as the most proper base of the future Christian iconographical repertoire, particularly of the icon of the Mother of God. The vicinity of the family or mortal beings and the imperial or Divine ones exactly as Ambrose was meditating about Old Testament patriarchs, including as well as, Constantine the Great ${ }^{64}$, shows the certain aesthetic aspect, according to which also assistants (servants) of the Emperor could be invited into the artistic manner. The latter was arguably

primarily superintended by two monks "Leopardo" and "Paolino", who at the same time governed the church of St. Vitalis. Only the Pope Innocent I made a correction of the name by a special local decree. Cf. P. Arringhi, Roma subterranea novissima in qua post Antonium Bosium antesignanum, Jo. Severanum congre. Oratorii presbyterum, et celebres alios scriptores, antiqua christianorum et precipue Martyrum Coemeteria, tituli, monumenta, epitaphia, inscriptiones, ac nobiliora sanctorum sepulchra, sex libris distincta inlustrantur, vol. 1, Lutetiae Parisiorum 1659, 59-62 and 69.

${ }^{61}$ Cf. S. Heid, Romanness of Roman Christianity, in: A Companion to Roman Religion, ed. J. Rupke, Oxford 2011, 412-415.

${ }^{62}$ The liturgical feast service to the Saint Agnes survived in the oldest Christian liturgical service $\left(6^{\text {th }}-16^{\text {th }}\right.$ century), primarily in the Aquileian (6-9 $9^{\text {th }} \mathrm{ct}$.), in the Aquileian-Venetian rite $\left(12-16^{\text {th }}\right.$

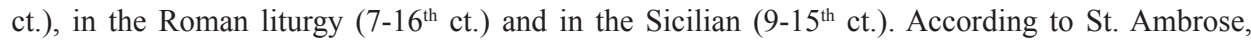
the martyr Agnes was born on 21 January around 304 (which is too late; the year 297 could be proposed), following the Orthodox feast calendar, could be associated with the memory date as of St. Virgin Agni (gr. Agne), later of St. Maximus the Confessor. According to the Athonite legend in the year 395 the son of Theodosius I, Arcadius, who fell from the ship during the storm nearby the Holy Month Athos, was saved because of his praying to Mother of God. The nearest monastery of the Holy Mont Athos therefore was named Vatopedi (gr. The bush of a child). Consequently the emperor Theodosius enlarged the monastery; on the place where Arcadius was saved the church was built, the feast of this the very first icon of Vatopedi was made on 2/3 February. Cf. Чудотворныле иконы Пресвятой Богородииы. Краткое описание. Иконография. Дни празднования. Тропари и молитвы. Молитвенная традииия, ред. С. Алексеев, Санкт Петербург 2010, 40.

${ }^{63}$ Ambrosius, De virginibus I 2, 6, SAEMO 14/1, ed. F. Gori, Milano - Roma 1977, 106.

${ }^{64}$ It existed also a fragment from the Letter of Constantine in the Ambrosian manuscript. Cf. G. Mercati, Antiche Reliquie Liturgiche Ambrosiane e Romane, Roma 1902, 67-69. 
recognized as the main characteristic (maxim) of the aesthetics of Constantine the Great ${ }^{65}$.

Indeed, Saint Agnes was one of the first saints, firstly mentioned in the "Ambrosian Canon", and placed as the fifth in the "Roman Canon", which was a direct product of Ambrose's pastoral activity in Milan. Consequently, Saint Agnes became an ideal model in the position of consecrated virginity ${ }^{66}$. The mentioned structure of a fluent passage from the written biblical to spoken liturgical manner was in the West truly penetrated by St. Ambrose in his personal hymns, prayers and liturgical service. The form that he introduced shows an exact scheme, denoted by unique oral Latin structure omitting the verb involvement, the most similar to ancient Latin meaning of "Carmen". Each hymn of St. Ambrose consisted of eight verses featuring four lines, almost always up to eight verses of eight syllables. The metrical rhythm of the iambic dimeters (originally classic) often coincided with the accentual rhythm of everyday speech in the congregational use ${ }^{67}$. In this manner Ambrose established the eastern practice of singing hymns and psalms, as St. Augustine admitted in his Confessions ${ }^{68}$, however it is not clear from which byzantine hymnographers St. Ambrose adopted the elements, as he could only be inspired by Gregory of Nyssa and Gregory of Nazianzus. But it is true enough that the Ambrosian rite, preserved in the manuscripts, was the oldest specimen of that type of spiritual song in the melismatic type, the most important part of which were the Alleluias ${ }^{69}$. More precisely, his innovation were also the antiphons, hymns and vigils that began to be celebrated in the Church of Milan, and quickly imitated by other local Roman Churches. By Ambrose the Church of Milan had got guided Vespers in Latin and the Ambrosian liturgy, differing considerably from the Roman use of the rest of churches of Italy. But towards the end of the $4^{\text {th }}$ century the Council of Laodicea (in the years 363-364) prohibited the singing of private psalms in churches, admitting by Canon 59 only "the book of the hundred and fifty psalms"70.

As the result the Orthodox theological context of St. Ambrose, regarded as a certain ecumenical aspect of his exegetical-theological thought, tacitly enforced the simultaneous usage of Western and Eastern version of the oldest liturgical rite ${ }^{71}$, supported by the musical structure that survived in manuscripts, could be reaffirmed. Ambrose's hymns, personal writings and treatises

${ }^{65}$ Cf. G. Mathew, Byzantine Aesthetics, London 1963, 48-52. The same principle could be noticed on the Arch of Constantine, on the bottom of the Column of Arcadius, in the second part of the illuminating images of Akhathist. See T. Velmans, Une illustration inedite de l'Acathiste et l'iconographie des hymnes liturgiques a Byzance, "Cahiers Archeologiques" 22 (1972) 153.

${ }^{66} \mathrm{Cf}$. Ambrosius, Hymnus XI (In sanctae Agnes uirginis et martyris) 19-20.

${ }^{67}$ Cf. Moorhead, Ambrose, p. 142.

${ }^{68}$ Cf. Augustinus, Confessiones IV 13 (Ps 118, 155), ibidem VI 1-3 (Ps 7, 11; Ps 17, 29).

${ }^{69} \mathrm{Cf}$. Wellesz, A History of Byzantine Music and Hymnography, p. 41.

${ }^{70}$ Concilium Laodicenum (363-364) can. 59, Mansi II, Florentiae 1759, 574.

${ }^{71}$ Cf. Mercati, Antiche Reliquie Liturgiche Ambrosiane e Romane, p. 36-43. 
reflected the dogmatic, linguistic and iconographic difficulties of the earlier establishment of the Christian state: from Nicene to Quinisextum (or from Constantine the Great to Justinian II as servus Dei on the coins with Christ's image), by which the Byzantine Empire entered the hardest historical-politic period of the iconoclasm (during the years 711-843).

It was at the Concile of Ephesus in 431 that the main part of biblical references had been defined. In "the Letter of Peace" the bishop John of Antioch in 431 on the way to Ephesus stated that the following Creed did not add anything to the Nicene doctrine, but confirmed it ${ }^{72}$. As a symbol of union,

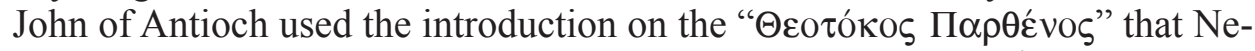
storius had already employed in his sermon of December $12^{\text {th }}$ in $430^{73}$. The Council of Chalcedon in 451 confirmed the ecumenical character of Nicene in $325^{74}$ and Constantinopole in $381^{75}$ Councils, but within the condemnation of the heresies of Nestorius, Apollinaris of Laodicea and Eutyches also defined the theologically untouchable position of the Mother of God. The pope Leo I approved the Tomus Leonis and testimonia, including the letters of Cyril of Alexandria to Nestorius ( $2^{\text {nd }}$ letter) and to the bishop John of Antioch, as the definition of faith for the Latin West (whereas in Egypt, Palestine, Syria and Armenia many ecclesiastics rejected it), but he did not accept ${ }^{76}$ the council's verdict (canon 6), promoting the see of Constantinople. The above-mentioned order of the Council of Laodicea of 363 was renewed by the Council of Braga in the year 563 in a more precise form: all hymns which were not based on passages from the Holy Scripture were excluded from use in the liturgical service $^{77}$. At the Council in Trullo (in the years 691 and 692) the daily preaching, especially on Sundays, was made obligatory for all higher clergy. At this ecumenical Council, regarded in the Byzantine East as the most important legislative council in history, the first step was made to define the conventions of Christian iconography, foremost regarding Christ's Divine nature (by the $82^{\text {nd }}$ canon the depiction of Jesus Christ as a lamb of God was prohibited, regarded as an undue concession to Judaism $)^{78}$.

\footnotetext{
${ }^{72}$ Cf. ACO I 1, Berlin 1927, 119.

${ }^{73}$ Cf. "Nestoriana", Die Fragmente des Nestorius, gesammelt, ed. F. Loofs, Halle 1905, 299.

${ }^{74}$ Cf. H. Chadwick, The Origin of the Title "Oecumenical Council”, JTS 23 (1972) 132-135.

${ }^{75}$ Cf. Concilium Chalcedonense (451). Definitio fidei (83-410), lines: 265-280, COGD 1, 134.

${ }^{76} \mathrm{Cf}$. Leo I papa, Epistula 114.

${ }^{77}$ Cf. Wellesz, A History of Byzantine Music and Himnography, p. 147.

${ }^{78}$ Cf. Concilium Trullanum (691-692) can. 82.
} 


\section{ŚWIĘTY AMBROŻY Z MEDIOLANU I UGRUNTOWYWANIE SIĘ CHRZEŚCIJAŃSTWA - TWORZENIE NOWEGO JĘZYKA DLA CHRZEŚCIJAN}

\section{(Streszczenie)}

Autor artykułu chce ukazać ortodoksyjny kontekst, będący efektem orzeczeń soborowych, traktowany jako pewien ekumeniczny aspekt myśli teologicznej św. Ambrożego, który milcząco wymuszał jednoczesne korzystanie z Zachodniej i Wschodniej tradycji liturgicznej. Pozycja Ambrożego jako biskupa Mediolanu, który głęboko rozpatrywał problemy dotyczące „nowego” języka chrześcijańskiego używanego w liturgii, a także problem historii Kościoła i liturgii, pozwoliła mu bezpośrednio wpływać na poprawę stosunków między Niceą Wschodu i Zachodu. Jego hymny, osobiste pisma i traktaty odzwierciedlały dogmatyczne, językowe i ikonograficzne trudności tworzenia się państwa chrześcijańskiego: od Nicei do Trullo (lub od Konstantyna Wielkiego do Justyniana II), przez które Bizancjum weszło ostatecznie w niezwykle trudny okres ikonoklazmu (w latach 711-843).

Key words: Nicene-Constantinopolitan Creed, St. Ambrose of Milan, Orthodoxy, theology, liturgical language, hymns.

Słowa kluczowe: nicejsko-konstantynopolitańskie wyznanie wiary, Ambroży z Mediolanu, ortodoksja, teologia, język liturgiczny, hymny. 
